\title{
ВПЛИВ СТУПЕНЯ ПОДРІБНЕННЯ НА ВИЛУЧЕННЯ БІОЛОГІЧНО АКТИВНИХ РЕЧОВИН ІЗ ПРИМУЛИ ДРІБНОЗУБЧАСТОЇ ЛИСТКІВ
}

Вступ. Створення нових фрітопрепаратів та вдосконалення технологій їх виробництва - важливий напрямок фрармацевтичної науки і практики. Екстрагування сировини є складним фрізико-хімічним процесом. На нього впливає багато чинників. Вагомим є вплив ступеня подрібнення рослинної сировини на інтенсифрікування процесу екстрагування.

Мета дослідження - визначити вплив ступеня подрібнення рослинної сировини на вилучення фрлавоноїдів та поліфенолів із примули дрібнозубчастої листків.

Методи дослідження. Кількісний вміст фрлавоноїдів та поліфенолів у витяжках, отриманих із сировини зі ступенем подрібнення 2 мм, 3 мм, 4 мм і 5 мм, визначали спектрофотометричним методом на спектрофотометрі Lambda 25 Perkin Elmer (США).

Результати й обговорення. Найбільшу кількість фрлавоноїдів екстраговано з витяжок із ступенем подрібнення примули дрібнозубчастої листків до 4 мм, їх вміст становив 344,82 мкг/мл. Найоптимальнішим був ступінь подрібнення сировини для вилучення поліфенолів 2 та 4 мм. Враховуючи результати попередніх досліджень, у ході яких встановлено, що фрракція 3-4 мм найменше поглинає екстрагенту, вирішено для оптимізації технології використовувати сировину зі ступенем подрібнення 4 мм.

Висновки. Спектрофотометричним методом встановлено кількісний вміст фрлавоноїдів та поліфенолів у витяжках із примули дрібнозубчастої листків. Вміст фрлавоноїдів у витяжках, одержаних із сировини зі ступенем подрібнення 2, 3, 4 та 5 мм, становить 328,48, 305,00, 344,82 і 293,39 мкг/мл відповідно. Кількісний вміст поліфенолів у витяжках, отриманих із сировини зі ступенем подрібнення 2, 3, 4 та 5 мм, складає 411,88, 396,25, 386,34 і 357,95 мка/мл відповідно. Найоптимальнішим є ступінь подрібнення примули дрібнозубчастої листків 4 мл, при якому вилучається найбільше фрлавоноїдів та поліфенолів і витрачається найменша кількість екстрагенту.

КЛЮчОВІ СЛОВА: примула дрібнозубчаста; листки; флавоноїди; поліфеноли; ступінь подрібнення сировини.

ВСТУП. Створення нових орітопрепаратів та вдосконалення технологій їх виробництва - важливий напрямок фрармацевтичної науки і практики. Завданням сучасної фрармації $€$ пошук нових видів, які б доповнили номенклатуру офріцинальних рослин. Виснаження запасів дикорослих рослин внаслідок нераціонального використання природних ресурсів спонукає застосовувати рослини культивованої фрлори.

До таких рослин належить примула дрібнозубчаста (Primula denticulata Smith) родини первоцвіті (Primulaceae). Ії̈ батьківщиною $€$ Гімалаї, Західний Китай, Афганістан і Пакистан.

K. Vetschera та співавт. встановили наявність у сировині примули дрібнозубчастої 5,8-дигідроксифрлавону, 5-гідроксисрлавону, 2'-гідроксифрлавону і 5,2'-дигідроксисрлавону [1]. Флаво(с) Л. І. Будняк, М. М. Васенда, 2019. ноїди рослини навіть у невеликій кількості проявляють сильні цитостатичні властивості [2].

Вміст сапонінів тритерпенового ряду в примули дрібнозубчастої листках і кореневищах 3 коренями становить 0,61 та 1,79 \% відповідно [3]. Тритерпенові сапоніни рослини проявляють муколітичні, відхаркувальні, діуретичні, гіпотензивні, протизапальні, антимікробні, протиалергічні та протипухлинні властивості [4].

A. Khaleefa та співавт., досліджуючи екстракти примули дрібнозубчастої, встановили їх антибактеріальні й антимітотичні ефекти. Екстракти проявляли інгібуючий вплив на грампозитивні та грамнегативні мікроорганізми: Escherichia coli, Staphylococcus aureus, Klebsiella pneumoniae, Salmonella typhi [5].

Екстрагування рослинної сировини є складним фрізико-хімічним процесом. На нього впли- 
вають такі чинники: природа екстрагенту, співвідношення сировини та екстрагенту, ступінь подрібнення рослинної сировини, температура, тривалість екстрагування [6].

Вагомим є вплив ступеня подрібнення рослинної сировини на інтенсифрікування процесу екстрагування, метою якого $є$ збільшення сумарної поверхні контакту сировини і розчинника, від якої залежить ступінь вичерпності сировини.

Мета дослідженння - визначити вплив ступеня подрібнення рослинної сировини на вилучення фрлавоноїдів та поліфенолів із примули дрібнозубчастої листків.

МЕТОДИ ДОСЛІДЖЕННЯ. Для експериментальних досліджень використовували примули дрібнозубчастої листки. Заготовляли сировину на території Тисменецького району (околиці с. Тязів) Івано-Франківської області в період цвітіння рослини у 2018 р.

Примули дрібнозубчастої листки подрібнювали за допомогою млинка на фрракції: 2 мм, 3 мм, 4 мм та 5 мм. Подрібнену сировину заливали етанолом (40 \%, об/об) Р у співвідношенні сировина та екстрагент 1:5, залишали настоюватись протягом 7-ми днів (метод екстрагування - мацерація).

Одержані витяжки зливали, фрільтрували та визначали в них біологічно активні речовини.

Кількісний вміст фрлавоноїдів та поліфенолів визначали спектрофотометричним методом на спектрофотометрі Lambda 25 Perkin Elmer (США) у кюветах з товщиною шару 10 мм [7].

Для визначення вмісту фрлавоноїдів аліквоту витяжки поміщали в мірну колбу місткістю 25 мл, додавали 10 мл етанолу (70 \%, об/об) Р, 2 мл 3 \% спиртового (70 \%) розчину алюмінію хлориду і доводили етанолом 70 \% Р до позначки, перемішували.

Компенсаційний розчин. Аліквоту отриманої витяжки поміщали в мірну колбу місткістю 25 мл і доводили об'єм розчину етанолом 70 \% Р до позначки, перемішували.

Розчин стандартного зразка рутину. 0,05 г (точна наважка) фрармакопейного стандартного зразка рутину поміщали в мірну колбу місткістю 100 мл, додавали 70 мл етанолу 70 \% Р, розчиняли та доводили об'єм розчину етанолом 70 \% Р до позначки, перемішували.

Розчин порівняння. 1 мл розчину стандартного зразка рутину поміщали в мірну колбу місткістю 25 мл, додавали 2 мл 3 \% спиртового (70 \%) розчину алюмінію хлориду і доводили етанолом 70 \% Р до позначки, перемішували.

Компенсаційний розчин. 1 мл розчину стандартного зразка рутину поміщали в мірну колбу місткістю 25 мл і доводили етанолом 70 \% Р до позначки, перемішували.

Оптичну густину випробовуваного розчину і розчину порівняння вимірювали через 45 хв після приготування при довжині хвилі 408 нм відносно компенсаційних розчинів для кожного відповідно.

Вміст фрлавоноїдів у витяжці (X) в перерахунку на рутин, мкг/мл, визначали за фрормулою:

$$
\mathrm{X}=\frac{\mathrm{A} \cdot \mathrm{m}_{0} \cdot 10000}{\mathrm{~A}_{0} \cdot \mathrm{V}_{\mathrm{a}}}
$$

де $\mathrm{A}$ - оптична густина випробовуваного розчину;

$\mathrm{A}_{0}$ - оптична густина розчину порівняння;

$\mathrm{m}_{\mathrm{o}}$ - маса наважки стандартного зразка рутину, г;

$\mathrm{V}_{\mathrm{a}}$ - об'єм аліквоти, взятої для аналізу, мл.

Вміст полісренолів визначали спектрофротометричним методом за методикою ДФУ 2.8.14.

Оптичну густину випробовуваних розчинів і розчину порівняння вимірювали через 30 хв при довжині хвилі 760 нм, використовуючи як компенсаційний розчин воду Р.

Вміст поліфенолів у витяжці (X) в перерахунку на пірогалол, мкг/мл, визначали за фрормулою:

$$
X=\frac{A \cdot m_{0} \cdot 25000}{A_{0} \cdot V_{a}},
$$

де $\mathrm{A}$ - оптична густина випробовуваного розчину;

$\mathrm{A}_{0}$ - оптична густина розчину порівняння;

$\mathrm{m}_{0}$ - маса наважки стандартного зразка пірогалолу, г;

$\mathrm{V}_{\mathrm{a}}$ - об'єм аліквоти, взятої для аналізу, мл [8].

РЕЗУЛЬТАТИ Й ОБГОВОРЕННЯ. СПЕКтрОфотометричним методом у примули дрібнозубчастої листках визначено кількісний вміст фрлавоноїдів, що залежав від ступеня подрібнення сировини (рис. 1).

Відповідно до рисунка 1, найбільшу кількість досліджуваних речовин - 344,82 мкг/мл екстраговано при ступені подрібнення сировини до $4 \mathrm{Mm}$.

Хороший результат отримано і при подрібненні сировини до 2 мм. У цьому випадку кількісний вміст фрлавоноїдів у витяжці становив 328,48 мкг/мл.

Найнижчу кількість фрлавоноїдів екстраговано при максимальному ступені подрібнення сировини - 5 мм, що в 1,17 раза менше порівняно 3 найкращим результатом.

Аналізуючи вилучення поліфенолів залежно від ступеня подрібнення примули дрібнозубчастої листків, одержали результати, які представлено на рисунку 2. 


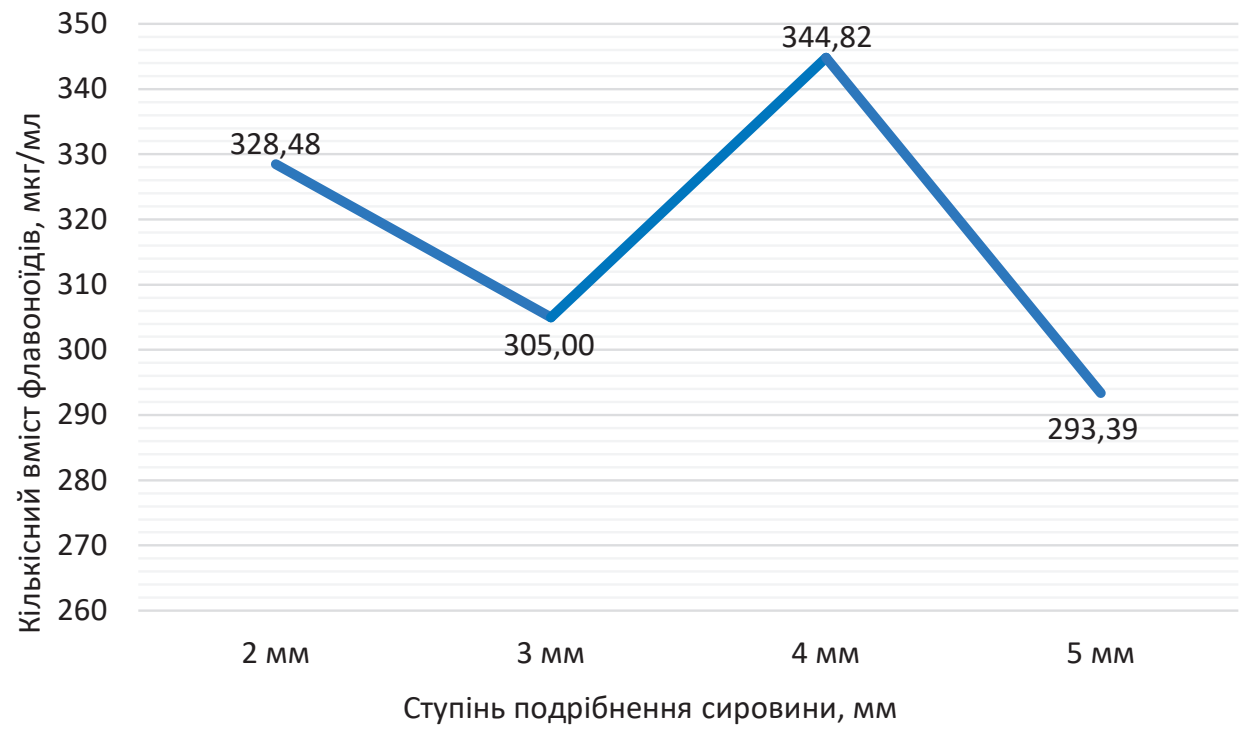

Рис. 1. Вплив ступеня подрібнення на вилучення фрлавоноїдів із примули дрібнозубчастої листків.

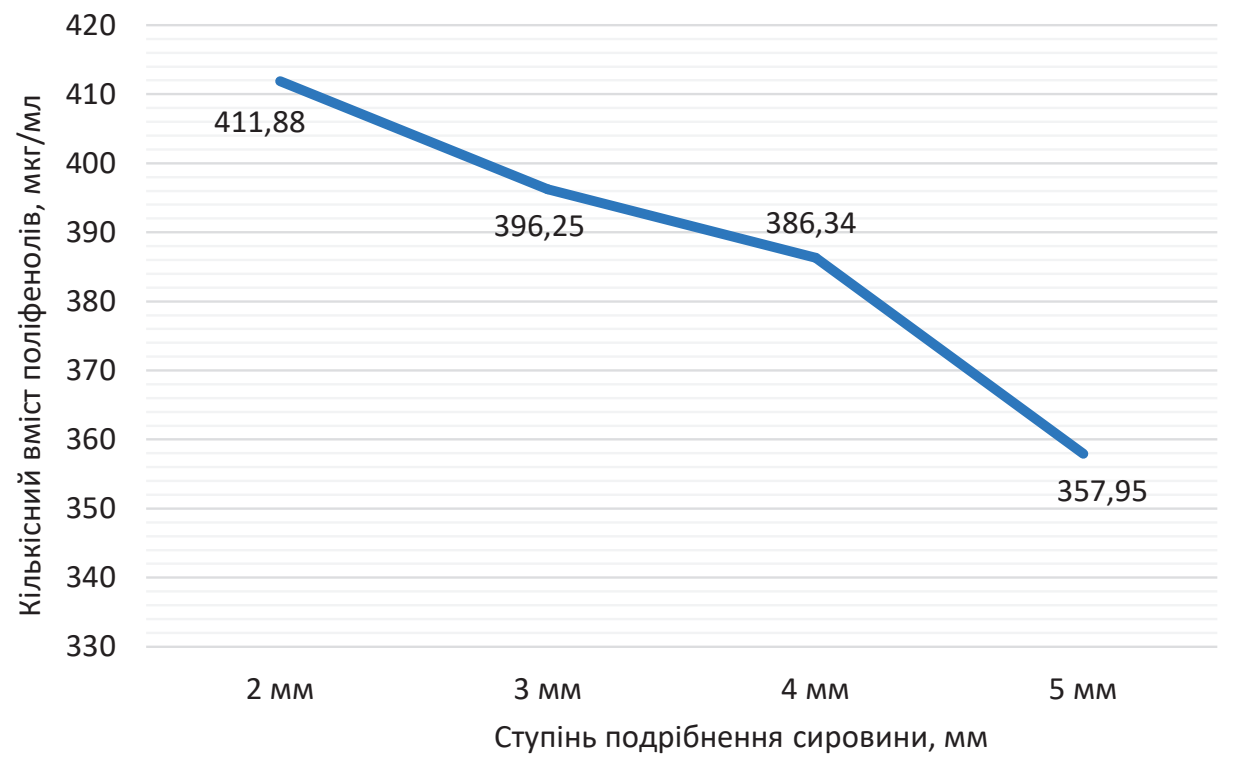

Рис. 2. Вплив ступеня подрібнення на вилучення поліфенолів із примули дрібнозубчастої листків.

Найоптимальнішим був ступінь подрібнення сировини 2 мм, при цьому екстрагувалася максимальна кількість фрлавоноїдів-411,88 мкг/мл. Також значна кількість поліфенолів переходила у витяжку при екстракції, коли ступінь подрібнення примули дрібнозубчастої листків становив 3 та 4 мм (396,25 і 386,34 мкг/мл). Найменша кількість поліфенольних сполук екстрагувалася при подрібненні сировини до 5 мм 357,95 мкг/мл.

У попередніх дослідженнях [9] встановлено, що фрракція 3-4 мм найменше поглинає екстрагенту, тому вирішено для оптимізації технології використовувати сировину зі ступенем подрібнення 4 мм, це дозволить зменшити витрати цінного екстрагенту.
ВИСНОВКИ. 1. Спектрофотометричним методом встановлено кількісний вміст фрлавоноїдів та поліфенолів у витяжках із примули дрібнозубчастої листків. Вміст фрлавоноїдів у витяжках, одержаних із сировини зі ступенем подрібнення 2, 3, 4 та 5 мм, становить 328,48, 305,00, 344,82 і 293,39 мкг/мл відповідно. Кількісний вміст поліфренолів у витяжках, отриманих із сировини зі ступенем подрібнення 2, 3, 4 та 5 мм, складає 411,88, 396,25, 386,34 і 357,95 мкг/мл відповідно.

2. Найоптимальнішим $€$ ступінь подрібнення примули дрібнозубчастої листків 4 мл, при якому вилучається найбільше фрлавоноїдів та поліфенолів і витрачається найменша кількість екстрагенту. 


\section{СПИСОК ЛІТЕРАТУРИ}

1. Vetschera K. Exudate flavonoids of Primula spp: structural and biogenetic chemodiversity / K. Vetschera, T. D. Bhutia, E. Wollenweber // Natural Product Communications. -2009 . -4 (3). - P. 365-370.

2. Biological effects of epicuticular flavonoids from Primula denticulata on human leukemia cells / S. V. Tokalov, B. Kind, E. Wollenweber, H. O. Gutzeit // Journal of Agricultural and Food Chemistry. - 2004. - 52 (2). P. 239-245.

3. Вміст сапонінів у листках і кореневищах з коренями культивованих видів роду Primula L. / A. B. Ciніченко, С. М. Марчишин, Л. І. Стойко, Л. В. Слободянюк // Мед. та клініч. хімія. - 2018. - 20, № 4 (77). C. 125-129.

4. Фармакогнозія: базовий підруч. для студ. вищ. фрармац. навч. закл. (фрармац. фр-тів) IV рівня акредитації / за ред. В. С. Кисличенко. - Х. : Золоті сторінки, 2015. - $736 \mathrm{c}$.

5. Khaleefa A. In vitro antioxidant, antibacterial activity and phytochemical studies of Primula denticulata - an important medicinal plant of Kashmir Himalaya / A. Khaleefa, A. N. Irshad, A. G. Bashir // International

\section{REFERENCES}

1. Vetschera, K., Bhutia, T.D., \& Wollenweber, E. (2009). Exudate flavonoids of Primula spp: structural and biogenetic chemodiversity. Natural Product Communications, 4 (3), 365-370.

2. Tokalov, S.V., Kind, B., Wollenweber, E., \& Gutzeit, H.O. (2004). Biological effects of epicuticular flavonoids from Primula denticulata on human leukemia cells. Journal of Agricultural and Food Chemistry, 52 (2), 239245.

3. Sinichenko, A.V., Marchyshyn S.M., Budniak L.I. \& Slobodianiuk L.V. (2018). Vmist saponiniv u lystkakh i korenevyshchakh z koreniamy kultyvovanykh vydiv rodu Primula L. [Content of saponins in leaves and rhizomes with roots of cultivated plants of Primula L.]. Med. $i$ klin. khimiia - Medical and Clinical Chemistry, 4, 125-129 [in Ukrainian].

4. Kyslychenko, V.S. (Ed.). (2015). Farmakohnoziia: bazovyi pidruch. dlia stud. vyshch. farmats. navch. zakl. (farmats. f-tiv) IV rivnia akredytatsii [Pharmacognosy: a basic textbook for students of higher pharmaceutical educational establishments (pharmaceutical faculties) of IV level of accreditation]. Kharkiv: Zoloti storinky [in Ukrainian].

5. Khaleefa, A., Irshad, A.N., Bashir, A.G. (2015). In vitro antioxidant, antibacterial activity and phytochemical studies of Primula denticulata - an important medicinal
Journal of Pharmacological Research. - 2015. - 5. P. 49-56.

6. Фітотерапія: стан і перспективи розвитку [Електронний ресурс] // Здоров'я України. - Режим доступу : http://www.health-ua.org/archives/health/407.html.

7. Стойко Л. І. Фармакогностичне дослідження золототисячника звичайного (Centaurium erythraea Rafn.) і тирлича хрещатого (Gentiana cruciata L.) родини Gentianaceae : дис. ... канд. фрармац. наук : 15.00.02 / Стойко Лілія Іллівна ; Національний фрармацевтичний університет. - Х., 2018. - 167 с.

8. Вронська Л. В. Обґрунтування вибору екстрагента біологічно активних речовин стулок квасолі звичайної / Л. В. Вронська // ScienceRise. - 2015. № 12 (4). - С. 47-53.

9. Васенда М. М. Вплив природи екстрагенту на вилучення фрлавоноїдів із листя примули дрібнозубчастої (Primula denticulata Smith) / М. М. Васенда, Л. І. Будняк, В. І. Сохацький // Science progress in European countries: new concepts and modern solutions: Papers of the $9^{\text {th }}$ International Scientific Conference (Stuttgart, 2019 September 6). - Stuttgart: ORT, 2019. P. 134-138.

plant of Kashmir Himalaya. International Journal of Pharmacological Research, 5, 49-56.

6. Fitoterapiia: stan i perspektyvy rozvytku [Phytotherapy: the state and prospects of development]. Retrieved from: http://www.health-ua.org/archives/health/ 407.html [in Ukrainian].

7. Stoiko, L.I. (2018). Farmakohnostychne doslidzhennia zolototysiachnyka zvychainoho (Centaurium erythraea Rafn.) i tyrlycha khreshchatoho (Gentiana cruciata L.) rodyny Gentianaceae [Pharmacognostic research of Centaurium erythraea Rafn. and Gentiana cruciata L. of Gentianaceae family]. Candidate's thesis. Kharkiv [in Ukrainian].

8. Vronska, L.V. (2015). Obhruntuvannia vyboru ekstrahenta biolohichno aktyvnykh rechovyn stulok kvasoli zvychainoi [Rationale for choice of extractant of biologically active substances of Phaseolus vulgaris pods]. ScienceRise, 12 (4), 47-53 [in Ukrainian].

9. Vasenda, M.M., Budniak, L.I., \& Sokhatskyi, B.I. (2015). Vplyv pryrody ekstrahentu na vyluchennia flavonoidiv iz lystia prymuly dribnozubchastoi (Primula denticulata Smith) [The influence of the nature of the extractant on the extraction of flavonoids from the leaf of primrose denticulated (Primaula denticulata Smith)]. Papers of the $9^{\text {th }}$ International Scientific Conference. Stuttgart (pp. 134-138). Stuttgart: ORT. 


\section{ВЛИЯНИЕ СТЕПЕНИ ИЗМЕЛЬЧЕНИЯ НА ИЗВЛЕЧЕНИЕ БИОЛОГИЧЕСКИ АКТИВНЫХ ВЕЩЕСТВ ИЗ ПРИМУЛЫ МЕЛКОЗУБЧАТОЙ ЛИСТЬЕВ}

\section{Резюме}

Вступление. Создание новых фритопрепаратов и усовершенствование технологий их производства важное направление фрармацевтической науки и практики. Экстрагирование сырья является сложным оризико-химическим процессом. На него влияет много фракторов. Весомым является влияние степени измельчения растительного сырья на интенсифицирование процесса экстрагирования.

Цель исследования - определить влияние степени измельчения растительного сырья на извлечение фрлавоноидов и полифенолов с примулы мелкозубчатой листьев.

Методы исследования. Количественное содержание фрлавоноидов и полифренолов в вытяжках, полученных из сырья со степенью измельчения 2 мм, 3 мм, 4 мм и 5 мм, определяли спектрофотометрическим методом на спектрофротометре Lambda 25 Perkin Elmer (США).

Результаты и обсуждение. Наибольшее количество фрлавоноидов экстрагировано с вытяжек со степенью измельчения примулы мелкозубчатой листьев до 4 мм, их содержание составляло 344,82 мкг/мл. Наиболее оптимальной была степень измельчения сырья для извлечения полифенолов 2 и 4 мм. Учитывая результаты предыдущих исследований, в ходе которых установлено, что орракция 3-4 мм меньше всего поглощает экстрагента, решено для оптимизации технологии использовать сырье со степенью измельчения 4 мм.

Выводы. Спектрофотометрическим методом установлено количественное содержание фрлавоноидов и полифренолов в вытяжках с примулы мелкозубчатой листьев. Содержание фрлавоноидов в вытяжках, полученных из сырья со степенью измельчения 2, 3, 4 и 5 мм, составляет 328,48, 305,00, 344,82 и 293,39 мкг/мл соответственно. Количественное содержание полифренолов в вытяжках, полученных из сырья со степенью измельчения 2, 3, 4 и 5 мм, составляет 411,88, 396,25, 386, 34 и 357,95 мкг/мл соответственно. Самой оптимальной является степень измельчения примулы мелкозубчатой листьев 4 мм, при которой извлекается больше всего фрлавоноидов и полифенолов и тратится наименьшее количество экстрагента.

КЛЮЧЕВЫЕ СЛОВА: примула мелкозубчатая; листья; фрлавоноиды; полифенолы; степень измельчения сырья.

L. I. Budniak, M. M. Vasenda

I. HORBACHEVSKY TERNOPIL NATIONAL MEDICAL UNIVERSITY

\section{THE EFFECT OF DISPERSITY ON THE REMOVAL OF BIOLOGICALLY ACTIVE SUBSTANCES OF PRIMROSE DENTICULATA LEAVES}

\section{Summary}

Introduction. The creation of new herbal products and the improvement of their production technologies is an important area of pharmaceutical science and practice. Raw material extraction is a complex physicochemical process. Many factors influence the extraction process. The influence of the dispersity of plant raw materials on the intensification of the extraction process is significant.

The aim of the study - to determine the influence of the dispersity of plant raw materials on the extraction of flavonoids and polyphenols of the primula denticulata leaves.

Research Methods. The quantitative content of flavonoids and polyphenols in extracts from leaf fractions of $2 \mathrm{~mm}, 3 \mathrm{~mm}, 4 \mathrm{~mm}$ and $5 \mathrm{~mm}$ was determined by spectrophotometric method on a Lambda 25 Perkin Elmer spectrophotometer.

Results and Discussion. The largest amount of flavonoids was extracted from extracts with the disperisty of the leaves of the primula denticulata to $4 \mathrm{~mm}$, their content is $344.82 \mu \mathrm{g} / \mathrm{ml}$. The most optimal degree of dispersity of raw materials for the extraction of polyphenols is $2 \mathrm{~mm}$ and $4 \mathrm{~mm}$. Considering the results of previous studies, 
which found that the fraction of 3-4 $\mathrm{mm}$ is the least absorbent of the extractant, it is decided to use raw materials with a degree of dispersity of $4 \mathrm{~mm}$ to optimize the technology.

Conclusions. The quantitative content of flavonoids and polyphenols in extracts from the primula denticulata leaves was determined by spectrophotometric method. The content of flavonoids in the extracts obtained from raw materials with a dispersity of 2, 3, 4 and $5 \mathrm{~mm}$ was 328.48, 305.00, 344.82 and $293.39 \mu \mathrm{g} / \mathrm{ml}$, respectively. The quantitative content of polyphenols in the extracts from raw materials with a dispersity of 2, 3, 4 and $5 \mathrm{~mm}$ was 411.88, 396.25, 386.34 and $357.95 \mu \mathrm{g} / \mathrm{ml}$, respectively. The most optimum dispersity of the primula denticulate leaves, in which most flavonoids and polyphenols are extracted and the least amount of extractant is consumed is the raw material with a dispersity of $4 \mathrm{~mm}$.

KEY WORDS: primrose denticulata; leaves; flavonoids; polyphenols; dispersity of raw materials.

Отримано 16.10.19

Адреса для листування: М. М. Васенда, Тернопільський національний медичний університет імені І. Я. Горбачевського мОз Украӥни, майдан Волі, 1, Тернопіль, 46001, Україна, e-mail: vasenda@tdmu.edu.ua. 